\title{
A Solid Binding Matrix/Mimic Receptor-Based Sensor System for Trace Level Determination of Iron Using Potential Measurements
}

\author{
Ayman H. Kamel, Felismina T. C. Moreira, Tamara I. Silva, and M. Goreti F. Sales
}

REQUIMTE, Instituto Superior de Engenharia do Porto, Rua Benardino de Almeida 431, 4200-072 Porto, Portugal

Correspondence should be addressed to M. Goreti F. Sales, goreti.sales@gmail.com

Received 14 March 2011; Accepted 2 May 2011

Academic Editor: Vinod Kumar Gupta

Copyright ( 2011 Ayman H. Kamel et al. This is an open access article distributed under the Creative Commons Attribution License, which permits unrestricted use, distribution, and reproduction in any medium, provided the original work is properly cited.

Iron(II)-(1,10-phenanthroline) complex imprinted membrane was prepared by ionic imprinting technology. In the first step, $\mathrm{Fe}$ (II) established a coordination linkage with 1,10-phenanthroline and functional monomer 2-vinylpyridine (2-VP). Next, the complex was copolymerized with ethylene glycol dimethacrylate (EGDMA) as a crosslinker in the presence of benzoyl peroxide (BPO) as an initiator. Potentiometric chemical sensors were designed by dispersing the iron(II)-imprinted polymer particles in 2-nitrophenyloctyl ether (o-NPOE) plasticizer and then embedded in poly vinyl chloride (PVC) matrix. The sensors showed a Nernstian response for $\left[\mathrm{Fe}(\mathrm{phen})_{3}\right]^{2+}$ with limit of detection $3.15 \mathrm{ng} \mathrm{mL}^{-1}$ and a Nernstian slope of $35.7 \mathrm{mV}$ per decade.

\section{Introduction}

Heavy metals constitute an important class of pollutants that degrade the environment due to their persistent nature and their industrial importance. Among these, iron is one of the most common metals in nature. Infiltration from rainwater in soils and underlying geologic formations dissolves iron, transporting it into groundwater. Large quantities of iron are also disposed in the environment as a result of anthropogenic activities. Iron and its compounds have widespread industrial applications, from constructional material for drinkingwater pipes, to food colours, coagulants in water treatment, pigments in paints and plastics. In tap water, dissolved ferrous iron gives a disagreeable taste. An appropriate knowledge of iron levels in both environmental waters and water for human consumption is very desirable. The relevancy of this subject has conducted to numerous reported methods using UV/Vis spectrophotometry [1-12], chemiluminescence [13-17], atomic absorption spectroscopy [18-22], and voltammetry $[23,24]$. The design and development of portable devices such as sensors rather than laboratory-based instruments in monitoring iron at trace levels in real samples is still of considerable interest.
Imprinted materials in sensors have attracted considerable attention during the past few years [25-27]. Molecular imprinting mimics natural receptors with regard to their molecular/ionic recognition. Most investigations of molecular imprinting polymers have been carried out using polymerization in the presence of the template in order to incorporate specific template sites into the polymer. The development of synthetic membranes with molecular imprinting functionality is an important approach for future functional separation or purification materials [28].

Ionic imprinting is a process, in which a functional monomer is allowed to self-assemble around templated ions and subsequently is crosslinked as required. The selectivity of a specific target ion is obtained by providing the polymers with cavities, in which complexing ligands are arranged to match charge, coordination number, coordination geometry and size of that target ion. This process creates the ionic recognition site, which is a specific location for the target ion chemical functionality and spatial arrangement. Recent developments in molecular imprinting have been reviewed [29]. The high selectivity of ion-imprinted polymers (IIPs) arises from the memory effect of the polymer to the imprinted ions for example, from the specificity of interaction 
of ligand with the metal ions, the coordination geometry and coordination number of metal ions; the charge of the metal ions and to a large extent on the size of them [30]. In recent years, a lot of IIPs have been prepared for $\mathrm{Pd}^{2+}$ [31], $\mathrm{Ni}^{2+}[32,33], \mathrm{Fe}^{3+}[34], \mathrm{Cd}^{2+}[35,36], \mathrm{Zn}^{2+}[37], \mathrm{Cu}^{2+}$ [38], Dy [39], $\mathrm{UO}_{2}^{2+}[40-42], \mathrm{Ca}^{2+}[43], \mathrm{Er}^{3+}[44], \mathrm{Th}^{4+}[45]$, $\mathrm{Hg}^{2+}[46]$, and $\mathrm{Gd}^{3+}[47,48]$.

The integration of IIP materials in electrochemical sensors yields selective, sensitive, simple, and rapid analytical methods. Electrochemical transducers monitor the activity of a chemical species in a given matrix and rely on interactions between analyte and receptor. Host-guest interactions are coupled to a signal transduction mechanism that yields the useful information about the species involved. The binding between the analyte and receptor can be effectively monitored and measured by such electrochemical techniques.

In this study, an ion-imprinting polymer was introduced for selective extraction of iron complex from aqueous solution. In synthesis processes, 1,10-phenanthroline, 2-vinylpyridine (2-VP), ethyleneglycol dimethacrylate (EGDMA), and benzoyl peroxide (BPO) were used as Fe(II) complexing agent, monomer, crosslinker and initiator, respectively. The synthesized polymer was dispersed in 2-nitrophenyloctyl ether (NPOE) and embedded in polyvinylchloride (PVC) matrix, for the monitoring of traces of iron.

\section{Experimental}

2.1. Apparatus. All potential measurements between reference and indicator electrodes were measured by means of a Crison $\mu \mathrm{pH} 2002$ decimilivoltammeter $( \pm 0.1 \mathrm{mV}$ sensitivity). An Orion, 90-00-29, double-junction electrode was used as reference. The analytical output signal was transferred to a commutation point reconnected to one of six ways out, each with an electrical antenna connector for adaptation to electrode device. The selective electrodes had no internal reference solution and an epoxy-graphite matrix as conductive solid contact. All measurements were carried out with the electrochemical cell graphite contact |Fe selective membrane| test solution $\| \mathrm{Na}_{2} \mathrm{SO}_{4}$ salt bridge II $\mathrm{Ag} / \mathrm{AgCl}(3 \mathrm{M} \mathrm{KCl})$. The $\mathrm{pH}$ values were measured by a Crison CWL/S7 combined glass electrode connected to a decimilivoltammeter Crison, pH meter, GLP 22. All potential measurements were carried out under constant stirring, by a Crison micro ST 2038. Infrared spectra were collected in a Nicolet 6700 FTIR spectrometer. Atomic absorption spectrometric measurements of $\mathrm{Fe}(\mathrm{II})$ were made with PerkinElmer spectrometer (AAnalyst 200) using the recommended optimum conditions [49].

2.2. Reagents and Solutions. All chemicals were of analytical grade and deionized water (conductivity $<0.1 \mu \mathrm{S} \mathrm{cm}^{-1}$ ) was employed throughout. 1,10 phenanthroline (phen), $o$ nitrophenyloctyl ether (o-NPOE), Bis(2-ethylhexyl)sebacate (BEHS) dibutyl phthalate (DBP), cyclodextrin $\left(\mathrm{Fe}^{\circ} \mathrm{Cyc}\right)$, tetrakis(4-chlorophenyl) borate, sodium tetraphenyl borate $\left(\mathrm{TPB}^{-}\right), \mathrm{PVC}$ of high molecular weight, 4-vinyl pyridine (4-VP), and ethyleneglycoldimethacrylate (EGDMA) were purchased from Fluka. Tetrahydrofuran (THF), acetic acid, citric acid, benzoyl peroxide (BPO), and ammonium iron sulfate were obtained from Riedel-deHaën. The evaluation of the effect of $\mathrm{pH}$ and other interfering species required sodium hydroxide, hydrochloride acid, cadmium sulphate, potassium sulphate, sodium chloride (all purchased from Merck), nickel chloride, manganese sulfate, magnesium chloride (all from Chemika), barium chloride (Sigma), silver nitrate, and copper sulfate (from Riedel-deHaën).

A solution of $0.1 \mathrm{~mol} \mathrm{~L}^{-1}$ of 1,10-phenanthroline was prepared in $10 \%$ ethanol. A $0.1 \mathrm{~mol} \mathrm{~L}^{-1}$ stock solution of $\mathrm{Fe}^{2+}$ was prepared by dissolving $4.0 \mathrm{~g}$ of iron(II) ammonium sulfate in $3 \mathrm{~mL}$ of $0.5 \mathrm{~mol} \mathrm{~L}^{-1} \mathrm{H}_{2} \mathrm{SO}_{4}$, diluted with water in $100 \mathrm{~mL}$ calibration flask. A $10^{-2} \mathrm{~mol} \mathrm{~L}^{-1}$ stock solution of tris-(1,10-phenanthroline) iron(I1) (ferroin) was prepared by mixing $10 \mathrm{~mL}$ of standard $10^{-1} \mathrm{~mol} \mathrm{~L}^{-1}$ iron(II) ammonium sulphate, $30 \mathrm{~mL}$ of $10^{-1} \mathrm{~mol} \mathrm{~L}^{-1} 1,10$-phenanthroline and $10 \mathrm{~mL}$ acetate buffer ( $\mathrm{pH}$ 4.7). The mixture was transferred into an $100 \mathrm{~mL}$ volumetric flask and made up to the mark with water. Standard ferroin solutions $\left(10^{-3}-10^{-8}\right.$, mol L ${ }^{-1}$ ) were prepared by accurate dilution.

Solutions of the diverse ions used in the interference study were $0.01 \mathrm{~mol} \mathrm{~L}^{-1}$ in buffer. Hydroxylamine hydrochloride solution $(10 \% \mathrm{w} / \mathrm{v})$ was prepared by dissolving the reagent in water. Acetate buffer solutions of $\mathrm{pH} 3.5-$ 6.6 were freshly prepared by mixing the appropriate amounts of $1 \mathrm{~mol} \mathrm{~L}^{-1}$ acetic acid and $1 \mathrm{~mol} \mathrm{~L}^{-1}$ sodium acetate solutions. All these solutions were stored in polyethylene containers.

2.3. Preparation of Ion Exchanger Sensor. It was carried out by mixing $50 \mathrm{~mL}$ of a $1.0 \times 10^{-2} \mathrm{~mol} \mathrm{~L}^{-1} \mathrm{Fe}(\mathrm{II})$ solution with $50 \mathrm{~mL}$ of a $1.0 \times 10^{-2} \mathrm{~mol} \mathrm{~L}^{-1}$ sodium TPB solution or tetrakis(4-chlorophenyl)borate. Resulting solid was isolated by filtration, thoroughly washing with water, and kept in a dark flask inside a desiccator in order to prevent alterations caused by light and humidity.

2.4. Preparation of Metal Complex Imprinted Polymers. In a typical preparation of $\mathrm{Fe}^{2+}$ imprinted polymer (IIP), 1.0 mmol 1,10-phenanthroline, and $1.0 \mathrm{mmol}\left(\mathrm{NH}_{4}\right)_{2} \mathrm{FeSO}_{4}$. $6 \mathrm{H}_{2} \mathrm{O}$ were weighed, placed into a $18 \mathrm{~mm}$ glass test tube and dissolved in $3 \mathrm{~mL}$ ethanol. To it $2.0 \mathrm{mmol} 4-\mathrm{VP}, 20 \mathrm{mmol}$ EGDMA, and $70 \mathrm{mg}$ BPO were added. The polymerization mixture were purged with nitrogen gas for $10 \mathrm{~min}$, sealed, and then heated in a water bath at $60^{\circ} \mathrm{C}$ for $1 \mathrm{~h}$. The resultant bulk polymer was ground and sieved, collected, and washed with ethanol/acetic acid $(5: 1)(\mathrm{V} / \mathrm{V})$ overnight to remove the template. The reference polymer (NIP) was similarly prepared but without $\left(\mathrm{NH}_{4}\right)_{2} \mathrm{FeSO}_{4} \cdot 6 \mathrm{H}_{2} \mathrm{O}$ and 1,10-phenanthroline during the polymerization.

\subsection{Constructions and Calibrations of Iron Membrane with} Imprinted Material. The sensing membranes were prepared by mixing $200 \mathrm{mg}$ of PVC powder and $7.0 \mathrm{mg}$ of MIP and $2.0 \mathrm{mg}$ of potassium tetrakis [2-chlorophenyl] borate [ISE I], $6.7 \mathrm{mg}$ of MIP only [ISE II], $7.0 \mathrm{mg}$ of NIP, and $2.0 \mathrm{mg}$ of potassium tetrakis[2-chlorophenyl]borate [ISE 
III], $7.0 \mathrm{mg}$ of NIP and $2.0 \mathrm{mg}$ of potassium tetrakis[2chlorophenyl]borate [ISE IV], and $2.0 \mathrm{mg}$ of potassium tetrakis[2-chlorophenyl]borate [ISE V], with $400 \mathrm{mg}$ of plasticizer $o$, NPOE and $200 \mathrm{mg}$ of PVC. The mixture was stirred until the PVC was well moistened and dispersed in $3.0 \mathrm{~mL}$ THF. These membranes were placed in conductive supports of conventional or tubular shapes. Membranes were allowed to dry for $24 \mathrm{~h}$ and placed in a $1 \times 10^{-3} \mathrm{~mol} \mathrm{~L}^{-1}$ $\left[\mathrm{Fe}(\mathrm{phen})_{3}\right]^{2+}$ solution. The electrodes were stored in these conditions when not in use.

All potentiometric measurements were carried out at room temperature. The emf of each electrode was measured in buffer. Different concentrations were obtained by transferring different aliquots of $1.0 \times 10^{-3} \mathrm{~mol} \mathrm{~L}^{-1}$ of $\left[\mathrm{Fe}(\text { phen })_{3}\right]^{2+}$ ions aqueous solutions to $100 \mathrm{~mL}$ beaker containing $50.0 \mathrm{~mL}$ of $10^{-2} \mathrm{~mol} \mathrm{~L}^{-1}$ acetate buffer of $\mathrm{pH} 4.7$. Potential readings were recorded after stabilization to $\pm 0.2 \mathrm{mV}$, and emf was plotted as a function of logarithm iron(II) concentration. Calibration graphs were used for subsequent determination of unknown iron(II) concentrations (see Table 1).

2.6. Constructions and Calibrations of Iron Membrane with Ion Exchange Material. Sensor solutions were prepared by dissolving an appropriate amount of sensor in about $62 \%$ BEHS or DBP. These were added of $32 \%$ of PVC formerly dissolved in $2 \mathrm{~mL}$ of THF. Composition of the resulting membranes is presented in Table 1. After application in the conventional support, each membrane was let dry for $24 \mathrm{~h}$.

All electrodes were placed in a convenient support over a magnetic stirrer and immersed in $50.00 \mathrm{~mL}$ of IS or buffer solution. Suitable increments of a $2.00 \times 10^{-2} \mathrm{~mol} \mathrm{~L}^{-1}$ $\mathrm{Fe}(\mathrm{II})$ standard solution were added to provide a series of $\mathrm{Fe}(\mathrm{II})$ concentrations ranging $4.10 \times 10^{-6} \mathrm{~mol} \mathrm{~L}^{-1}$ to $3.33 \times 10^{-3} \mathrm{~mol} \mathrm{~L}^{-1}$. The potential readings of the stirred $\mathrm{Fe}(\mathrm{II})$ solutions were measured at room temperature and recorded after stabilization to $\pm 0.1 \mathrm{mV}$. A calibration plot was constructed connecting logarithm concentration with electromotive force.

\section{Results and Discussion}

Positioning of metal ions to match the arrangement of ligands on a substrate molecule through preorganization of the substrate with a metal-complexing monomer and its subsequent crosslinking polymerisation is an attractive means to prepare synthetic receptor materials. Furthermore, the strength and specificity of metal-ligand coordination may be enhanced by choosing the suitable functional groups for the IIP.

Despite the potential advantages offered by metal-coordination interaction, relatively few efforts have been taken to use this binding mode to design molecularly imprinted polymers. In this work, a noncovalent molecular imprinting method $[50,51]$ was used to synthesize a synthetic host for ferroin.

3.1. FTIR Spectra. Figure 1 presents the FTIR spectra of (a) IIP, (b) NIP, (c) $\mathrm{FeSO}_{4}$, and (d) 1,10-phenanthroline. It can be seen that the shape and position of most peaks in (a)

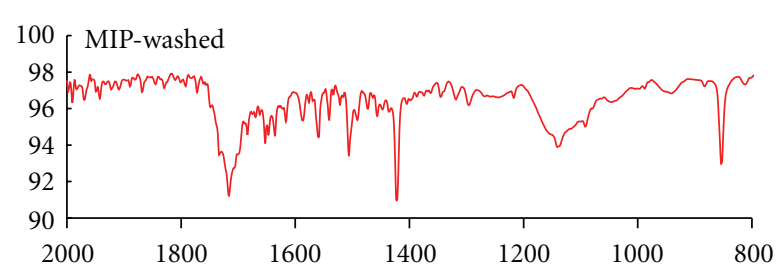

(a)

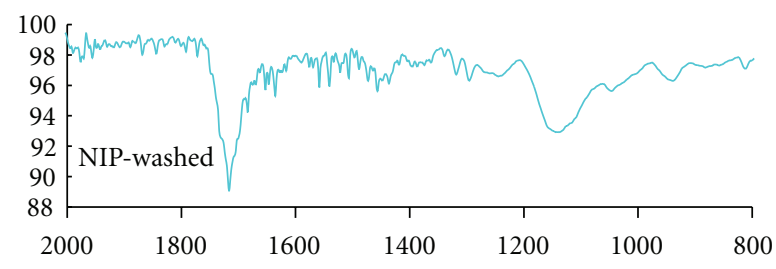

(b)

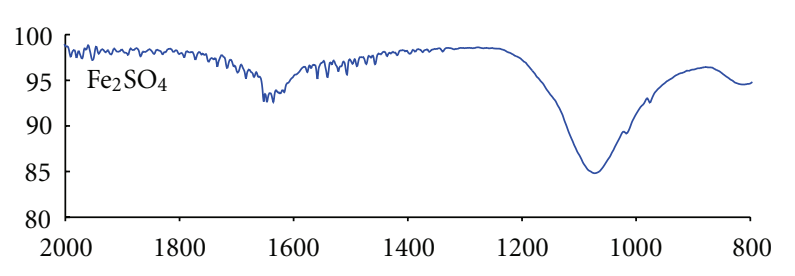

(c)

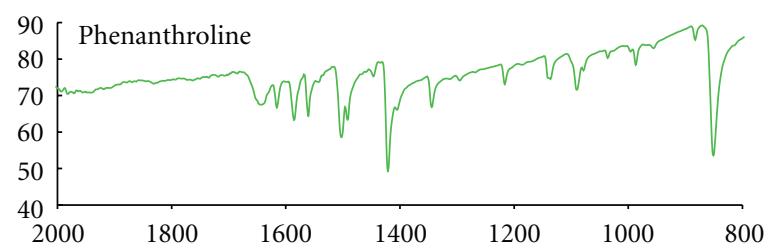

(d)

Figure 1: FTIR spectra of IIP (a), NIP (b), FeSO4, and 1,10phenanthroline (d). (Scan from 2000 to $800 \mathrm{~cm}^{-1}$, with background correction, and room temperature/humidity control).

and (b) spectra are similar. This was as expected, because both polymers have the same chemical functions. The slight difference between these was related to some ferroin complex sequestered within the imprinted matrix. This is confirmed by (d) spectra; the peak at $853.5 \mathrm{~cm}^{-1}$ should correspond to absorption band of $\mathrm{C}-\mathrm{H}$ stretching vibration for $\mathrm{H}$ atoms adjacent in the pyridine ring in 1,10-phenanthroline compound. The characteristic ring frequencies in 1,10phenanthrene were shown at approximately $1502 \mathrm{~cm}^{-1}$ the second appearing as a triplet with the centre component at $1585 \mathrm{~cm}^{-1}$ and the third band shifting to $1423 \mathrm{~cm}^{-1}$. The $1423 \mathrm{~cm}^{-1}$ band was most sensitive in this respect, but the other two showed a slightly discernable shift of the order of 10 to $25 \mathrm{~cm}^{-1}$.

3.2. Binding Studies. Adsorption isotherms yield important information concerning binding energies, modes of binding, and site distributions in the interaction of small molecules with adsorbent surfaces. In the liquid phase applications of imprinted materials, a molecule in solution interacts with binding sites in a solid adsorbent. The adsorption isotherms 


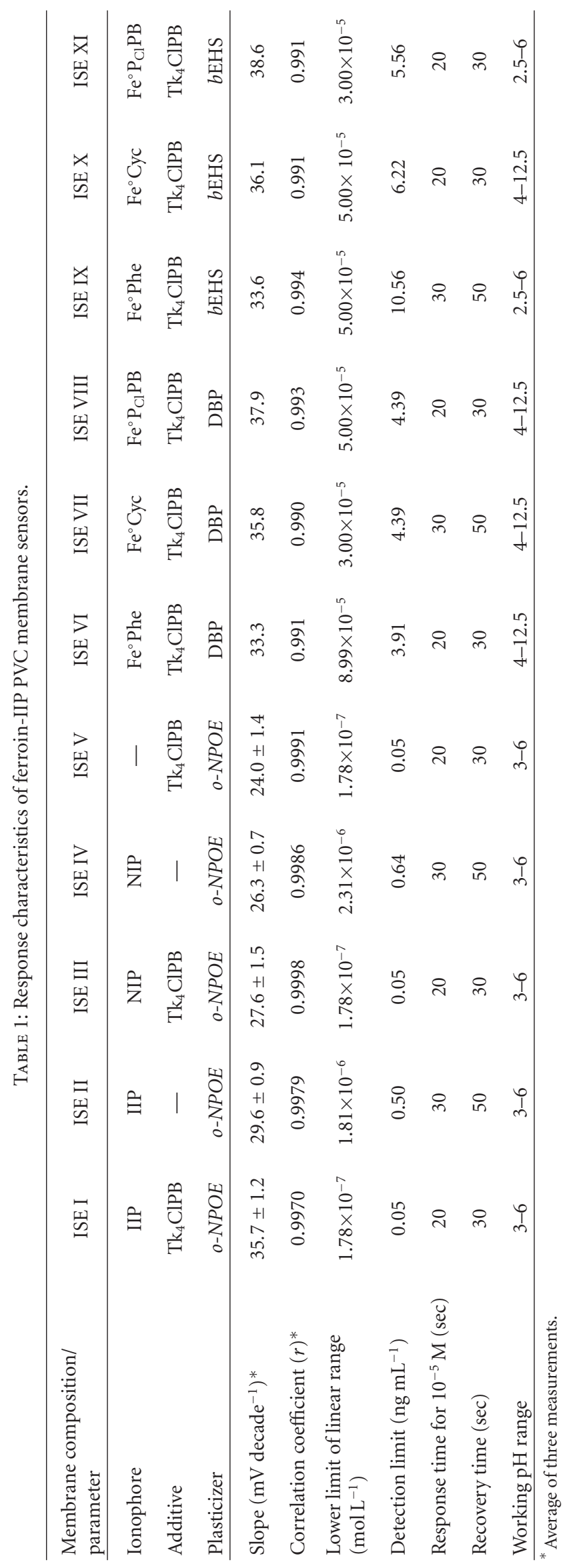




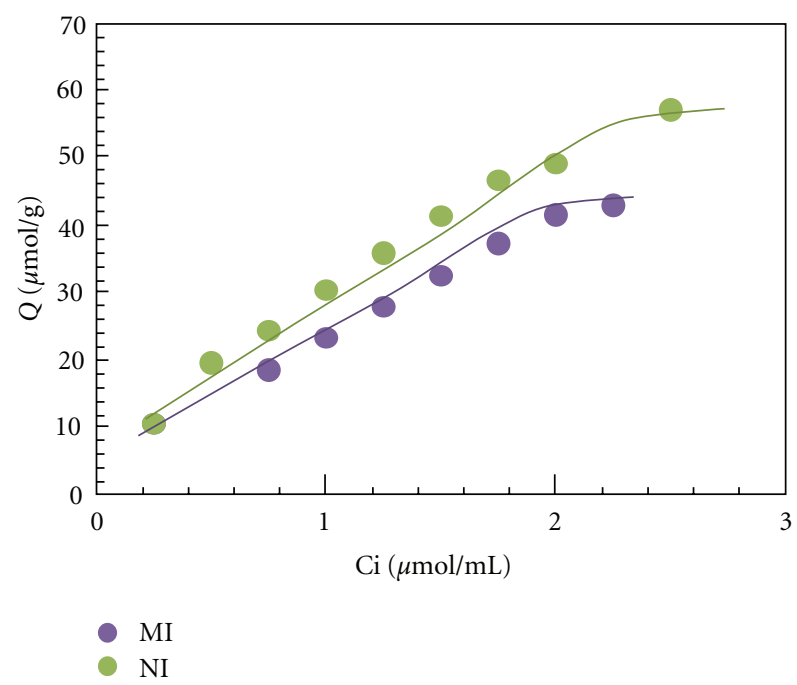

(a)

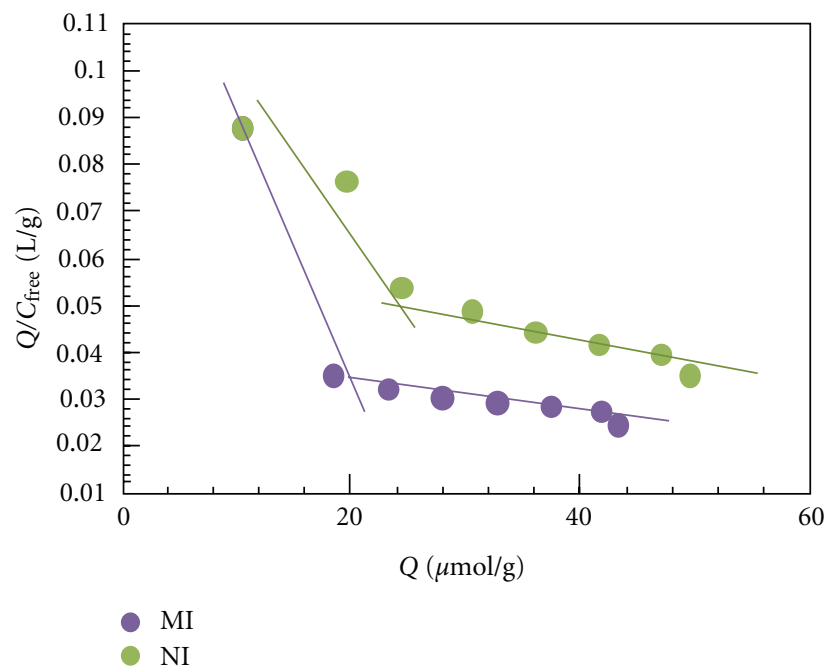

(b)

FIgURE 2: Binding isotherm (a) and Scatchard plot (b) for the Ferroin-imprinted (MI) or nonimprinted (NI) polymer. $Q=$ Ferroin bound to $50.0 \mathrm{mg}$ of the corresponding polymer; temperature $=25^{\circ} \mathrm{C}$; volume $=4.00 \mathrm{~mL}$; binding time: $12 \mathrm{~h}$.

are then simply plots of the equilibrium concentrations of bound ligand (adsorbate) versus the concentration of free ligand. The isotherms can be fitted using various models. The most simple is the Langmuir type adsorption isotherm, where the adsorbent is assumed to contain only one type of site; adsorbate-adsorbate interactions are assumed not to occur, and the system is assumed ideal.

In order to investigate the binding performance of IIP, the equilibrium binding experiments were carried out by varying the concentrations $\left[\mathrm{Fe}(\text { phen })_{3}\right]^{2+}$ complex from $0.2 \mathrm{mmol} \mathrm{L}^{-1}$ to $2 \mathrm{mmol} \mathrm{L}^{-1}$ in the presence of a fixed amount $(50 \mathrm{mg})$ of IIP and the obtained data were plotted with the Scatchard analysis [52] to estimate the binding parameters of IIP

$$
\frac{Q}{C}=\frac{\left(Q_{\max }-Q\right)}{K_{d}}
$$

where $Q_{\max }$ is the maximum apparent binding capacity and $K_{d}$ the equilibrium dissociation constant. As shown in Figure 2(a), the Scatchard plot is not linear, indicating that the binding sites in either IIP or NIP are heterogeneous in respect to the affinity for $\left[\mathrm{Fe}(\mathrm{phen})_{3}\right]^{2+}$. Clearly, within the plot, there are two distinct sections and two straight lines can be obtained from the linear regression. This indicates that the binding sites in the IIP and NIP could be classified into two distinct groups with specific binding properties $\left(K_{d}\right) l$ and $\left(Q_{\max }\right) l$ of higher affinity binding sites can be calculated to be $152.4 \mu \mathrm{mol} \mathrm{L}^{-1}$ and $24.5 \mu \mathrm{mol} \mathrm{g}^{-1}$ dry polymer for IIP and NIP, respectively, from the slope and the intercept of the Scatchard plot (Figure 2(b)). Similarly, $\left(K_{d}\right) 2$ and $\left(Q_{\max }\right) 2$ of lower affinity binding sites were $3251.2 \mu \mathrm{mol} \mathrm{L}^{-1}$ and $129.1 \mu \mathrm{mol} \mathrm{g}^{-1}$, respectively.

\subsection{ISEs Analytical Features}

3.3.1. Imprinting Polymer. The dissolution of MIP within the selective membrane may conduct to alterations at the configuration of the imprinted shape. When the template is not extracted from the imprinted polymer, this change in configuration may be attenuated. Results obtained pointed out that template extraction was important, providing decreased limit of detection and higher sensitivity. These results suggest that configuration changes from MIP dissolution were not significant, even for NIP sensors. The synthesized IIP were incorporated into the PVC membrane and were tested as sensing materials in the proposed potentiometric sensor. The potential response obtained with the sensors prepared with $\left[\mathrm{Fe}(\text { phen })_{3}\right]^{2+}$ IIP membrane and blank membrane is given in Figure 3. As seen from the figure, the sensors exhibit linear potentiometric response to $\left[\mathrm{Fe}(\mathrm{phen})_{3}\right]^{2+}$ ions with lower limit of linear range $1.81 \times 10^{-6}$ and $2.31 \times 10^{-6}, 1.78 \times 10^{-7} \mathrm{~mol} \mathrm{~L}^{-1}$, and detection limits of $4.45,6.89$, and $17.7 \mathrm{ng} \mathrm{mL}^{-1}$, for ISE's [II], [IV], and [V], respectively. All sensors exhibit near-Nernstian slopes of $29.6 \pm 0.9\left(r^{2}=0.9979\right), 26.3 \pm 0.7$ and $24.0 \pm 1.4 \mathrm{mV}$ decade $^{-1}$, respectively. Addition of anionic additive potassium tetrakis[2-chlorophenyl]borate to either MIP [ISE I] or NIP [ISE III]-based membrane resulted in a Nernestian pattern with a slope $35.7 \pm 1.2\left(r^{2}=0.9979\right)$ and $27.6 \pm 1.5$ $\left(r^{2}=0.9998\right) \mathrm{mV} \mathrm{decade}{ }^{-1}$, lower limit of linear range of $1.78 \times 10^{-7}$ and $2.0 \times 10^{-7} \mathrm{~mol} \mathrm{~L}^{-1}$, and lower detection limit of 3.15 and $5.12 \mathrm{ng} \mathrm{mL}^{-1}$, respectively. The composition and potentiometric response characteristics of the membrane sensors incorporating MIP and NIP as selective ion recognitions and with/without tetrakis[2-chlorophenyl]borate as anionic additive are shown in Table 1.

3.3.2. Ion Exchanger Sensor. Six membrane compositions were prepared by varying electroactive materials and solvent plasticizers (Table 1). Complexes of iron with phenanthroline, cyclodextrin, or tetrakis(4-chlorophenyl)borate served as ionophores and BEHS or DPB were used as plasticizers. All membranes were of plasticized PVC with 31-32 wt $\%$ 


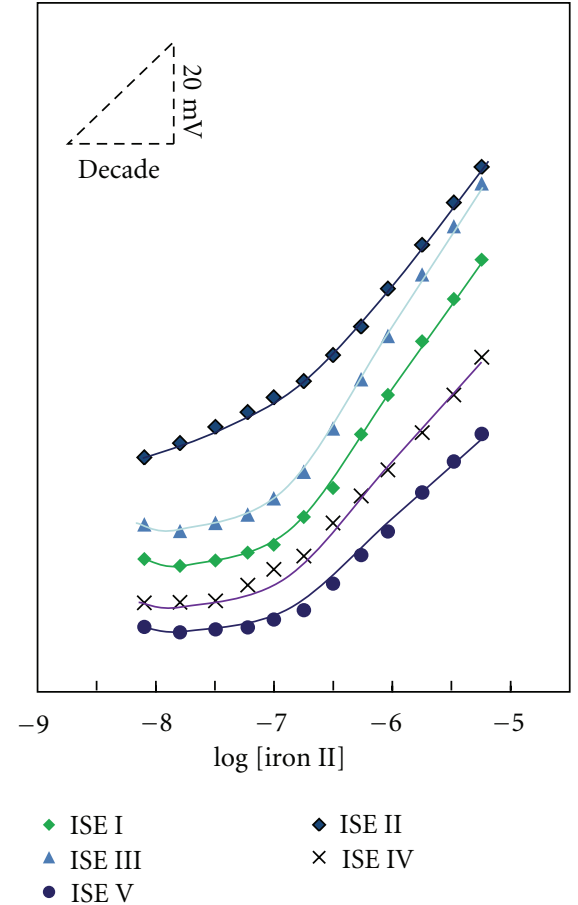

FIGURE 3: Calibration curve in acetate buffer at $\mathrm{pH} 4.7$ for different sensors.

PVC, $61-63 \mathrm{wt} \%$ plasticizing solvent and 3\%-4\% of anionic additive and $3 \mathrm{wt} \%$ of electroactive material.

Electrodes showed supra-Nernstian responses in buffer (Table 1). Slopes ranged 33.3 to $38.6 \mathrm{mV}$ decade $^{-1}$ and linear behavior was mainly observed from $3.0 \times 10^{-5}$ up to $3.3 \times 10^{-3} \mathrm{~mol} \mathrm{~L}^{-1}$. Sensors of $\mathrm{Fe}^{\circ} \mathrm{Cyc}$ or $\mathrm{Fe}^{\circ} \mathrm{PClPB}$ were greatly dependent on the plasticizing solvent, showing better responses for DBP.

3.4. Effect of PH. The influence of $\mathrm{pH}$ on the potentiometric response of the proposed sensors was examined over a $\mathrm{pH}$ range of 3-10 for $\left[\mathrm{Fe}(\mathrm{phen})_{3}\right]^{2+}$ standard solutions of $1.0 \times$ $10^{-5} \mathrm{~mol} \mathrm{~L}^{-1}$. The $\mathrm{pH}$ of the solution was adjusted with either hydrochloric acid and/or sodium hydroxide solutions. The $\mathrm{pH}$ plot shows that the variation of solution $\mathrm{pH}$ over the range 3-6 has no significant effect on the potentiometric response for all membrane based sensors.

For the ion exchange membranes the potential versus $\mathrm{pH}$ profiles show that the electrodes do not respond to $\mathrm{pH}$ changes in the ranges 2.5-6 for sensors IX and XI and $\mathrm{pH} 4-$ 12.5 for sensors VI, VII, VIII, and X. Only sensors IX and XI showed the effect of the severe precipitation of metals taking place in the alkaline range. All other sensors showed no effect from $\mathrm{pH}$ within this range. This is most evidently an abnormal behaviour for which no logical explanation may be found.

Because the solubility and ionisation of Fe(II) were both promoted by acidic solutions, studies under constant $\mathrm{pH}$ were carried out in the acidic range.

Evaluation of main operating features for all electrodes under constant $\mathrm{pH}$ was carried out in several buffer solutions prepared with different $\mathrm{pHs}$ within 2 and 6 . Results showed that electrodes provided slopes ranging 67.0 to $202.2 \mathrm{mV}$ decade- 1 in citric acid $\mathrm{pH} 2.5,33.3$ to $40.6 \mathrm{mV}$ decade1 in citric acid $\mathrm{pH} 4$, and 29.4 to $137.7 \mathrm{mV}$ decade- 1 in citric acid $\mathrm{pH} 6$, over a wide concentration range. Best general analytical features for all electrodes were achieved with citrate buffer of $\mathrm{pH} 4$.

3.5. Response Time. The dynamic response times of the sensors were examined by recording the potential readings at time intervals of $10 \mathrm{~s}$ over $2 \mathrm{~min}$. The time required to reach $95 \%$ of equilibrium was $\sim 20 \mathrm{~s}$ for electrodes [I, III, and V] with a recovery time $\sim 30$ and $\sim 30$ s for electrodes [II and IV] with a recovery time $\sim 50 \mathrm{~s}$. These results indicate that both sensors are amenable for use with automated systems.

3.6. Selectivity Studies. The selectivity of the chemical sensor is one of the most important potentiometric features. One component of the selective membrane exerting great influence upon this property is the electroactive material, as the mechanism of selectivity is mainly based on stereospecificity and electrostatic environment. It is dependent on how much fitting is present between locations of the lipophilicity sites in the two competing species in the bathing solution side and those present in the sensor [53]. The performance of the ferroin sensor in the presence of some cations was assessed by measuring the selectivity coefficient values $\log K_{\mathrm{Fe}^{2+}, J^{z+}}^{\mathrm{POT}}$ using the separate solutions method [54]. The results obtained showed no effect for high concentrations ( $>1000$-fold excess) of many common cations such as $\mathrm{NH}_{4}^{+}, \mathrm{Na}^{+}, \mathrm{K}^{+}, \mathrm{Ba}^{2+}$, $\mathrm{Ca}^{2+}$, and $\mathrm{Mg}^{2+}$. These cations do not form complexes with 1,10-phenanthroline reagent. Metal ions known to form insoluble metal phenanthroline chelates or metal halides (e.g., $\mathrm{Pb}^{2+}, \mathrm{Hg}^{2+}$, and $\mathrm{Ag}^{+}$) did not interfere. Metals which form water soluble charged complexes with phenanthroline such as $\mathrm{Zn}^{2+}, \mathrm{Cu}^{2+}, \mathrm{Ni}^{2+}$, and $\mathrm{Cd}^{2+}$ interfered seriously but interferences caused by these cations were completely circumvented by using suitable masking agents. The response behavior of the MIP and NIP membrane-based sensors towards these complexed cations were presented in Figure 4.

3.7. Analytical Application. In order to access the applicability of the iron selective electrodes, the potentiometric method was applied for the determination of iron in different materials of various natures by formation of ferroin followed by monitoring with the IIP-ferroin sensor. Iron contents $\left(0.05-0.30 \mathrm{mg} \mathrm{L}^{-1}\right)$ of different tap water collected from the laboratory taps and were added of buffer prior to analysis in order to ensure similar background as that of standard solutions were determined. The samples spiked with various standard iron concentrations display results agreed fairly well within $\pm 1.5 \%$ with those obtained with the standard spectrophotometric method. Determination of $\mathrm{Fe}^{2+}$ in the presence of large quantities of $\mathrm{Fe}^{3+}$ has received considerable attention in corrosion and environmental studies. Several reports confirmed that the spectrophotometric ferroin method for determining $\mathrm{Fe}^{2+}$ in the presence of excess $\mathrm{Fe}^{3+}$ is not reliable and the recovery of $\mathrm{Fe}^{2+}$ is always high [55]. 
TABLE 2: Potentiometric determination of iron in some pharmaceutical formulation samples using the proposed ferroin sensors.

\begin{tabular}{lcccc}
\hline & & & \multicolumn{2}{c}{ Iron recovery $(\%)^{*}$} \\
Trade name & \multicolumn{2}{c}{ IIP sensor } & Hydrodynamic & Standard method \\
\hline Centrum & 14 & $95 \pm 0.5$ & $93 \pm 1.1$ & $98 \pm 0.1$ \\
(Wyeth, Portugal) & 90 & $98 \pm 0.1$ & $96 \pm 0.4$ & $99 \pm 0.3$ \\
\hline
\end{tabular}

TABLE 3: Analytical features of the present method reported in the literature.

\begin{tabular}{|c|c|c|c|c|c|c|c|}
\hline Technique/method & Principle of the method & $\begin{array}{l}\text { Detection } \\
\text { limit } \\
(\mathrm{mg} / \mathrm{L})\end{array}$ & $\begin{array}{l}\text { Linear } \\
\text { range } \\
(\mathrm{mg} / \mathrm{L})\end{array}$ & $\begin{array}{c}\text { Repeatability } \\
(\%)\end{array}$ & Application & Sample preparation & Ref. \\
\hline \multirow{4}{*}{$\mathrm{UV} / \mathrm{Vis}$} & $\begin{array}{l}\text { Iron complex with } \\
\text { 1-nitroso-2-naphhtol } \\
(446 \mathrm{~nm})\end{array}$ & $\begin{array}{c}1.7 \times 10 \\
-3\end{array}$ & $\begin{array}{c}1.7 \times 10^{-3}- \\
0.12\end{array}$ & 2.57 & $\begin{array}{l}\text { Industrial waste } \\
\text { water }\end{array}$ & (SPE) & {$[2]$} \\
\hline & $\begin{array}{l}\text { Catalytic } \\
\text { spectrophotometric flow } \\
\text { injection }(514 \mathrm{~nm})\end{array}$ & $20 \times 10^{-3}$ & $\begin{array}{c}\text { Up to } \\
2 \times 10^{-6}\end{array}$ & & $\begin{array}{l}\text { Real water } \\
\text { samples }\end{array}$ & $\begin{array}{l}\text { Filtered water samples } \\
\text { were acidified to } 0.1 \\
\text { M hydrochloric acid) }\end{array}$ & {$[3]$} \\
\hline & $\begin{array}{l}\text { Adaptation of the } \\
\text { ferrozine method } \\
(560 \mathrm{~nm})\end{array}$ & 5850 & $\begin{array}{l}1755 \text { to } \\
23400\end{array}$ & 2 & In situ analysis & No & {$[7]$} \\
\hline & $\begin{array}{l}\text { Reaction betwen } \\
\text { hydroquinone and } \\
\text { chromate in acidic } \\
\text { media }(350 \mathrm{~nm})\end{array}$ & 0.05 & - & - & - & No & {$[8]$} \\
\hline \multirow[t]{2}{*}{ Chemiluminescence } & Neutralisation reaction & 0.56 & $2.8-560$ & - & $\begin{array}{c}\text { Fresh water } \\
\text { samples }\end{array}$ & $\begin{array}{l}\text { Reduction of iron(III) } \\
\text { with }\end{array}$ & [13] \\
\hline & - & $5.85 \times 10^{-5}$ & $\begin{array}{l}14625 \text { to } \\
87750\end{array}$ & - & $\begin{array}{l}\text { Fresh water } \\
\text { samples }\end{array}$ & $\begin{array}{l}\text { Hydroxylammonium } \\
\text { chloride }\end{array}$ & {$[14]$} \\
\hline HPLC & $\begin{array}{l}\text { Photometric detection } \\
(550 \mathrm{~nm})\end{array}$ & $0.2 \times 10^{-3}$ & $\begin{array}{c}10 \times 10^{-3} \\
\text { to } 10\end{array}$ & - & Spiked tap water & No & {$[55]$} \\
\hline \multirow[t]{2}{*}{ Potentiometry/ISE } & $\begin{array}{l}\text { Chiral } \\
\text { 2,6-bis-(carboxamide } \\
\text { methyl ester)pyridine } \\
\text { derivative sensor, PVC } \\
\text { membrane }\end{array}$ & & $0.25-56.0$ & - & $\begin{array}{l}\text { Drug } \\
\text { formulations }\end{array}$ & - & {$[56]$} \\
\hline & $\begin{array}{l}\text { IIP sensor in a PVC } \\
\text { selective membrane }\end{array}$ & 4.45 & 0.014 & 2.4 & $\begin{array}{l}\text { Pharmaceutical } \\
\text { formulation } \\
\text { samples }\end{array}$ & No & $\begin{array}{l}\text { This } \\
\text { method }\end{array}$ \\
\hline
\end{tabular}

In the present work, mixtures of $\mathrm{Fe}^{2+}$ and $\mathrm{Fe}^{3+}$ covering the concentration ratios of $1: 1$ to $1: 50\left(\mathrm{Fe}^{2+}: \mathrm{Fe}^{3+}\right)$ were prepared and treated with 1, 10-phenanthroline at $\mathrm{pH} 4.7$. After a reaction time of $1 \mathrm{~min}$, EDTA was added to mask $\mathrm{Fe}^{3+}$, and $\left[\mathrm{Fe}(\mathrm{phen})_{3}\right]^{2+}$ was potentiometrically measured with the ferroin sensor. In a second run, the total iron $\left[\mathrm{Fe}^{2+}\right.$ and $\left.\mathrm{Fe}^{3+}\right]$ was assessed by a prior reduction with hydroxylamine and formation and measurement of ferroin. Results with average recoveries of $98.4 \%($ S.D. $=1.5 \%)$ and $95.7 \%($ S.D. $=1.4 \%)$ were obtained $(n=4)$ for iron(II) and iron(III), respectively.

The proposed sensor was also used to determine iron in pharmaceutical preparations both in batch and in flow conditions. The results obtained with some polyvitamin/mineral tablets and capsules showed an average recovery of $95.5 \%$ of the nominal value and a mean standard deviation of $\pm 0.9 \%$
(Table 2). These results were checked and confirmed by an independent method from the pharmacopoeia. The results obtained showed a close agreement between the data of the spectrophotometry and ferroin sensor, thus confirming the accuracy of the proposed method.

\section{Conclusions}

Proposed $\mathrm{Fe}$ potentiometric detectors are simple, of low cost, and easy to manipulate. The electrodes based on dispersion of mimic receptor for ferroin in PVC matrix and plasticized in $o$-NPOE might be useful detectors for analysis of environmental waters. They display high selectivity and wide dynamic response range. In general, the overall procedure is precise, accurate, and inexpensive regarding 


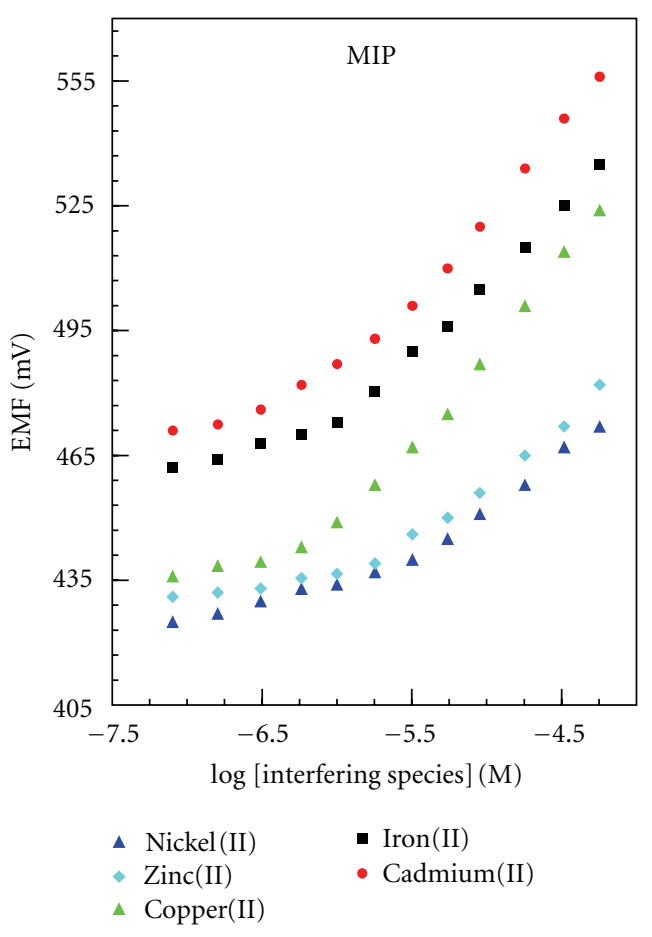

(a)

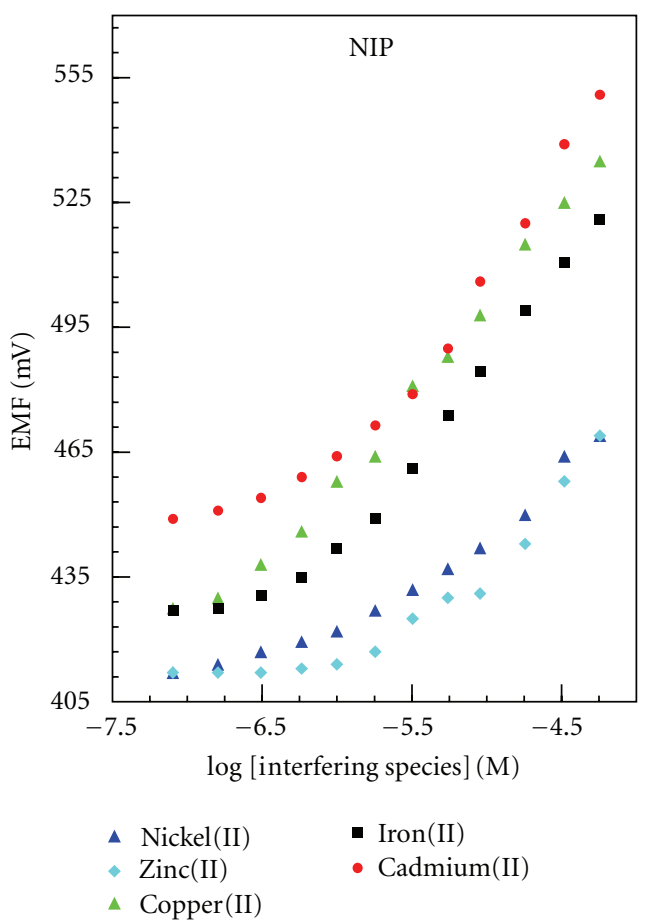

(b)

FIgURE 4: The response behavior of the proposed sensors towards different metal ion complexes.

reagent consumption and equipment involved, especially compared to other methods previously reported (Table 3 ). Considering its routine application, a main advantage arises from composition and quantity of emitted effluents, with small concern in terms of environmental issues. Aside from dilution with buffer, no sample pretreatment or separation steps are required.

\section{References}

[1] L. S. G. Teixeira and F. R. P. Rocha, "A green analytical procedure for sensitive and selective determination of iron in water samples by flow-injection solid-phase spectrophotometry," Talanta, vol. 71, no. 4, pp. 1507-1511, 2007.

[2] G. A. Shar and G. A. Soomro, "Derivative spectrophotometric determination of nickel (II) with 1-nitroso-2-naphthol in aqueous phase," Journal of the Chemical Society of Pakistan, vol. 28, p. 39, 2006.

[3] S. Lunvongsa, M. Oshima, and S. Motomizu, "Determination of total and dissolved amount of iron in water samples using catalytic spectrophotometric flow injection analysis," Talanta, vol. 68, no. 3, pp. 969-973, 2006.

[4] S. Lunvongsa, T. Tsuboi, and S. Motomizu, "Sequential determination of trace amounts of iron and copper in water samples by flow injection analysis with catalytic spectrophotometric detection," Analytical Sciences, vol. 22, no. 1, pp. 169172, 2006.

[5] M. A. Feres and B. F. Reis, "A downsized flow set up based on multicommutation for the sequential photometric determination of iron(II)/iron(III) and nitrite/nitrate in surface water," Talanta, vol. 68, no. 2, pp. 422-428, 2005.

[6] N. Devanna, K. P. Satheesh, and K. B. C. Sekhar, "Derivative spectrophotometric determination of iron(II) using diacetylmonoxime benzoyl hydrazone," Asian Journal of Chemistry, vol. 17, no. 3, pp. 1767-1772, 2005.

[7] P. M. Sarradin, N. Le Bris, C. Le Gall, and P. Rodier, "Fe analysis by the ferrozine method: adaptation to FIA towards in situ analysis in hydrothermal environment," Talanta, vol. 66, no. 5, pp. 1131-1138, 2005.

[8] D. Mihai, A. Rustoiu-Csavdari, and I. Baldea, "Potential application of the reaction between hydroquinone and chromate with respect to the kinetic determination of iron," Analytical and Bioanalytical Chemistry, vol. 381, no. 7, pp. 1362-1366, 2005.

[9] P. K. Tarafder and R. Thakur, "Surfactant-mediated extraction of iron and its spectrophotometric determination in rocks, minerals, soils, stream sediments and water samples," Microchemical Journal, vol. 80, no. 1, pp. 39-43, 2005.

[10] V. M. Ostrovskaya, N. V. Davidovskii, O. A. Prokopenko, and D. A. Man'Shev, "Rapid test determination of iron(II) in aqueous media by reagent indicator paper," Journal of Analytical Chemistry, vol. 59, no. 9, pp. 882-884, 2004.

[11] J. H. Chen, Q. F. Hu, G. Y. Yang, and J. Y. Yin, "Solid phase extraction and spectrophotometric determination of iron in water with 8-hydroxyquinadine," Chinese Journal oF Analytica l Chemistry, vol. 31, p. 853, 2003.

[12] A. Asan, M. Andac, and I. Isildak, "Flow-injection spectrophotometric determination of nanogram levels of iron(III) with N,N-dimethylformamide," Analytical Sciences, vol. 19, no. 7, pp. 1033-1036, 2003.

[13] B. R. M. Al-Gailani, G. M. Greenway, and T. McCreedy, "A miniaturized flow-injection analysis ( $\mu$ FIA) system with on-line chemiluminescence detection for the determination of iron in estuarine water," International Journal of Environmental Analytical Chemistry, vol. 87, no. 9, pp. 637-646, 2007. 
[14] M. Yaqoob, A. Waseem, and A. Nabi, "Determination of total iron in fresh waters using flow injection with potassium permanganate chemiluminescence detection," Journal of Analytical Chemistry, vol. 61, no. 9, pp. 917-921, 2006.

[15] J. G. Lv and Z. J. Zhang, "A microchip with air sampling and chemiluminescence detection for analyzing iron in nature water and in whole blood," Analytical Letters, vol. 37, no. 7, pp. 1401-1408, 2004.

[16] G. H. Zhu, H. X. Ju, and B. F. Ye, "A sensitive fluorescence quenching method for the determination of iron(II) with 1,10-phenanthroline," Chinese Journal of Chemistry, vol. 21, no. 2, pp. 301-320, 2003.

[17] W. Qin, Z. J. Zhang, and F. C. Wang, "Chemiluminescence flow system for the determination of $\mathrm{Fe}$ (II) and $\mathrm{Fe}$ (III) in water," Fresenius Journal of Analytical Chemistry, vol. 360, no. 1, pp. 130-132, 1998.

[18] S. Saracoglu, M. Soylak, D. S. K. Peker et al., "A preconcentration procedure using coprecipitation for determination of lead and iron in several samples using flame atomic absorption spectrometry," Analytica Chimica Acta, vol. 575, no. 1, pp. 133-137, 2006.

[19] Y. Bakircioglu, D. Bakircioglu, and N. Tokman, "A novel preconcentration method for determination of iron and lead using Chromosorb-103 and flame atomic absorption spectrometry," Analytica Chimica Acta, vol. 547, no. 1, pp. 2630, 2005.

[20] S. Tautkus, L. Steponeniene, and R. Kazlauskas, "Determination of iron in natural and mineral waters by flame atomic absorption spectrometry," Journal of the Serbian Chemical Society, vol. 69, no. 5, pp. 393-402, 2004.

[21] P. C. Aleixo and J. A. Nobrega, "Direct determination of iron and selenium in bovine milk by graphite furnace atomic absorption spectrometry," Food Chemistry, vol. 83, no. 3, pp. 457-462, 2003.

[22] A. Ohashi, H. Ito, C. Kanai, H. Imura, and K. Ohashi, "Cloud point extraction of iron(III) and vanadium(V) using 8-quinolinol derivatives and Triton X-100 and determination of 10-7 mol dm -3 level iron(III) in riverine water reference by a graphite furnace atomic absorption spectroscopy," Talanta, vol. 65, no. 2, pp. 525-530, 2005.

[23] N. Y. Stozhko, O. V. Inzhevatova, and L. I. Kolyadina, "Determination of iron in natural and drinking Waters by stripping voltammetry," Journal of Analytical Chemistry, vol. 60, no. 7, pp. 668-672, 2005.

[24] A. Bobrowski, K. Nowak, and J. Zarebski, "Application of a bismuth film electrode to the voltammetric determination of trace iron using a $\mathrm{Fe}$ (III)-TEA-BrO3- Catalytic system," Analytical and Bioanalytical Chemistry, vol. 382, no. 7, pp. 1691-1697, 2005.

[25] H. Yan and K. H. Row, "Characteristic and synthetic approach of molecularly imprinted polymer," International Journal of Molecular Science, vol. 7, no. 5, pp. 155-178, 2006.

[26] A. Katz and M. E. Davis, "Molecular imprinting of bulk, microporous silica," Nature, vol. 403, no. 6767, pp. 286-289, 2000.

[27] S.L. Gong, Z.J. Yu, L.Z. Meng, L. Hu, and Y.B. He, "Emolecular-imprinted polysiloxanes. II. Preparation, characterization, and recognition behavior," Journal of Applied Polymer Science, vol. 93, p. 637, 2004.

[28] T. Kobayashi, H. Y. Wang, and N. Fujii, "Molecular imprint membranes of polyacrylonitrile copolymers with different acrylic acid segments," Analytica Chimica Acta, vol. 365, no. 1-3, pp. 81-88, 1998.
[29] T. Takeuchi and J. Haginaka, "Separation and sensing based on molecular recognition using molecularly imprinted polymers," Journal of Chromatography B, vol. 728, no. 1, pp. 1-20, 1999.

[30] G. Wulff, "Molecular imprinting in cross-linked materials with the aid of molecular templates - a way towards artificial antibodies," Angewandte Chemie, vol. 34, no. 17, pp. 18121832, 1995.

[31] H. Zheng, D. Zhang, W. Y. Wang, Y. Q. Fan, J. Li, and H. P. Han, "Highly selective determination of palladium(II) after preconcentration using $\mathrm{Pd}(\mathrm{II})$-imprinted functionalized silica gel sorbent prepared by a surface imprinting technique," Microchimica Acta, vol. 157, p. 7, 2007.

[32] A. Ersöz, R. Say, and A. Denizli, "Ni(II) ion-imprinted solidphase extraction and preconcentration in aqueous solutions by packed-bed columns," Analytica Chimica Acta, vol. 502, no. 1, pp. 91-97, 2004.

[33] N. Jiang, X. J. Chang, H. Zheng, Q. He, and Z. Hu, "Selective solid-phase extraction of nickel(II) using a surface-imprinted silica gel sorbent," Analytica Chimica Acta, vol. 577, no. 2, pp. 225-231, 2006.

[34] X. J. Chang, N. Jiang, H. Zheng et al., "Solid-phase extraction of iron(III) with an ion-imprinted functionalized silica gel sorbent prepared by a surface imprinting technique," Talanta, vol. 71, no. 1, pp. 38-43, 2007.

[35] G. Z. Fang, J. Tan, and X. P. Yan, "An ion-imprinted functionalized silica gel sorbent prepared by a surface imprinting technique combined with a sol-gel process for selective solidphase extraction of cadmium(II)," Analytical Chemistry, vol. 77, p. 1734, 2005.

[36] F. Li, H. Q. Jiang, and S. S. Zhang, "An ion-imprinted silicasupported organic-inorganic hybrid sorbent prepared by a surface imprinting technique combined with a polysaccharide incorporated sol-gel process for selective separation of cadmium(II) from aqueous solution," Talanta, vol. 71, no. 4, pp. 1487-1493, 2007.

[37] Q. He, X. J. Chang, H. Zheng, N. Jiang, Z. Hu, and Y. Zhai, "Preconcentration and separation of $\mathrm{Zn} 2+$ using surface zinc(II) imprinted functionalized silica gel sorbent," Chemia Analityczna, vol. 51, no. 5, pp. 715-725, 2006.

[38] I. Fujiwara, A. Uchiyama, Y. Sasaki, M. Maeda, and M. Takagi, "Preparation of CuII-imprinted microspheres with imidazole groups at the surfaces by surface imprinting polymerization," Bunseki Kagaku, vol. 52, no. 2, pp. 147-150, 2003.

[39] N. Zhang, B. Hu, and C. Z. Huang, "A new ion-imprinted silica gel sorbent for on-line selective solid-phase extraction of dysprosium(III) with detection by inductively coupled plasma-atomic emission spectrometry," Analytica Chimica Acta, vol. 597, no. 1, pp. 12-18, 2007.

[40] S. Y. Bae, G. L. Southard, and G. M. Murray, "Molecularly imprinted ion exchange resin for purification, preconcentration and determination of UO22+by spectrophotometry and plasma spectrometry," Analytica Chimica Acta, vol. 397, no. 13, pp. 173-181, 1999.

[41] G. D. Saunders, S. P. Foxon, P. H. Walton, M. J. Joyce, and S. N. Port, "A selective uranium extraction agent prepared by polymer imprinting," Chemical Communications, no. 4, pp. 273-274, 2000.

[42] J. M. Gladis and T. P. Rao, "Synthesis and analytical applications of uranyl ion imprinted polymer particles," Analytical Letters, vol. 36, no. 10, pp. 2107-2121, 2003. 
[43] T. Rosatzin, L. I. Andersson, W. Simon, and K. Mosbach, "Preparation of $\mathrm{Ca} 2+$ selective sorbents by molecular imprinting using polymerisable ionophores," Journal of the Chemical Society, vol. 2, no. 8, pp. 1261-1265, 1991.

[44] R. Kala, J. M. Gladis, and T. P. Rao, "Preconcentrative separation of erbium from Y, Dy, Ho, Tb and Tm by using ion imprinted polymer particles via solid phase extraction," Analytica Chimica Acta, vol. 518, no. 1-2, pp. 143-150, 2004.

[45] S. Büyüktiryaki, R. Say, A. Ersöz, E. Birlik, and A. Denizli, "Selective preconcentration of thorium in the presence of UO 22+, Ce3+ and La3+ using Th(IV)-imprinted polymer," Talanta, vol. 67, no. 3, pp. 640-645, 2005.

[46] Y. Liu, X. Chang, D. Yang, Y. Guo, and S. Meng, "Highly selective determination of inorganic mercury(II) after preconcentration with $\mathrm{Hg}$ (II)-imprinted diazoaminobenzene-vinylpyridine copolymers," Analytica Chimica Acta, vol. 538, p. 85, 2005.

[47] O. Vigneau, C. Pinel, and M. Lemaire, "Ionic imprinted resins based on EDTA and DTPA derivatives for lanthanides(III) separation," Analytica Chimica Acta, vol. 435, no. 1, pp. 75-82, 2001.

[48] O. Vigneau, C. Pinel, and M. Lemaire, "Solid-liquid separation of lanthanide/lanthanide and lanthanide/actinide using ionic imprinted polymer based on a DTPA derivative," Chemistry Letters, no. 2, pp. 202-203, 2002.

[49] S. S. M. Hassan, Organic Analysis Using Atomic Absorption Spectrometry, Ellis Horwood, Chichester, UK, 1984.

[50] R. Arshady and K. Mosbach, "Synthesis of substrate-selective polymers by host-guest polymerization," Makromolekulare Chemie, vol. 182, pp. 687-692, 1981.

[51] A. H. Kamel, F. T. C. Moreira, S. A. A. Almeida, and M. G. F. Sales, "Novel potentiometric sensors of molecular imprinted polymers for specific binding of chlormequat," Electroanalysis, vol. 20, no. 2, pp. 149-202, 2008.

[52] N. T. A. Ghani, M. S. Rizk, and R. M. El-Nashar, "Salbutamol plastic membrane electrodes based on individual and mixed ion-exchangers of salbutamolium phosphotungstate and phosphomolybdate," Analyst, vol. 125, no. 6, pp. 1129 1133, 2000.

[53] IUPAC, "Analytical Chemistry Division Commission on Analytical Nomenclature," Pure and Applied Chemistry, vol. 72, p. $1851,2000$.

[54] H. Fadrus and J. Maly, "Suppression of iron(III) interference in the determination of iron(II) in water by the 1,10phenanthroline method," The Analyst, vol. 100, no. 1193, pp. 549-554, 1979.

[55] P. G. Rigas and D. J. Pietrzyk, "Indirect photometric detection in liquid chromatography using iron(II)-1,10-phenanthroline complex as a mobile phase additive: origin, calibration and parameters," Analytical Chemistry, vol. 60, pp. 454459, 1988.

[56] M. A. Abounassif, M. A. Al-Omar, A.-G. E. Amr, and G. A. E. Mostafa, "PVC membrane sensor for potentiometric determination of iron (II) in some pharmaceutical formulations based on a new neutral ionophore," Drug Testing and Analysis, vol. 3, pp. 373-379, 2011. 


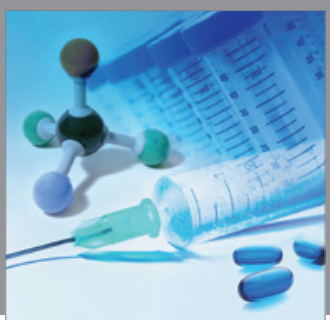

International Journal of

Medicinal Chemistry

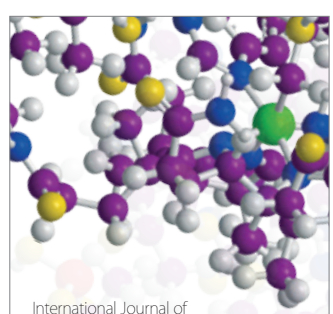

Carbohydrate Chemistry

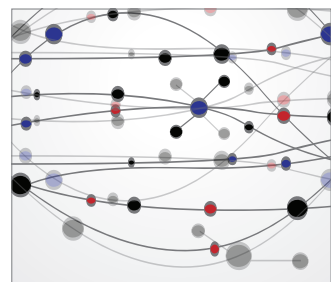

The Scientific World Journal
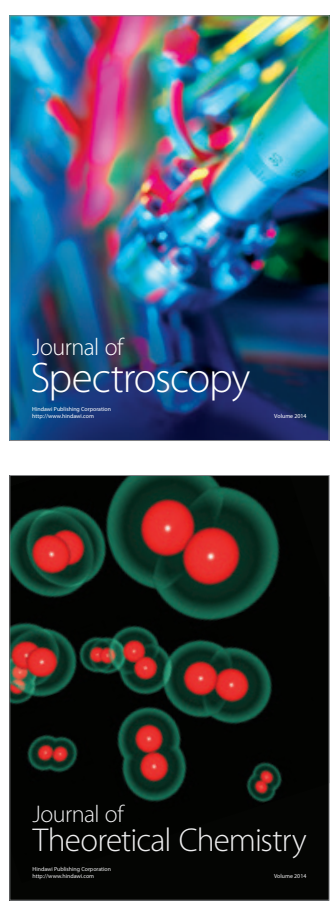
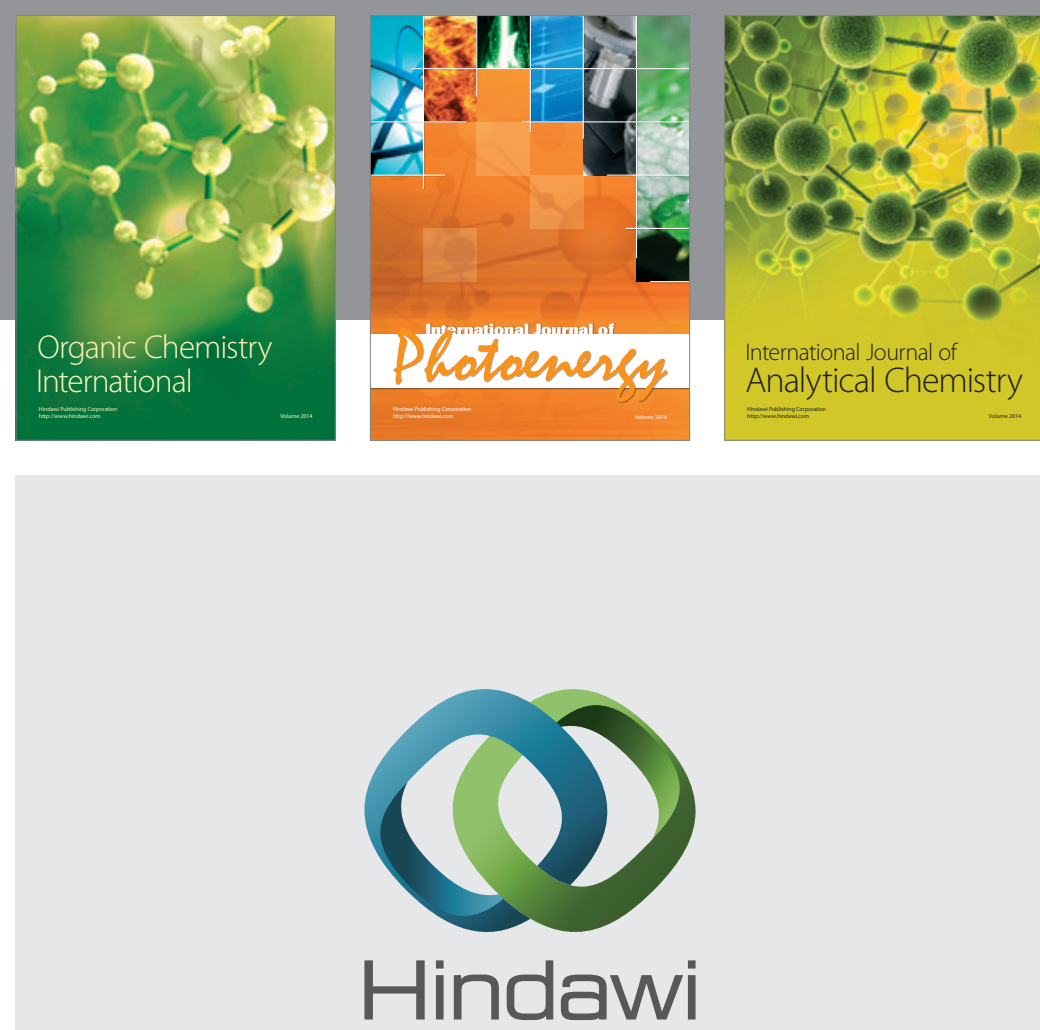

Submit your manuscripts at

http://www.hindawi.com
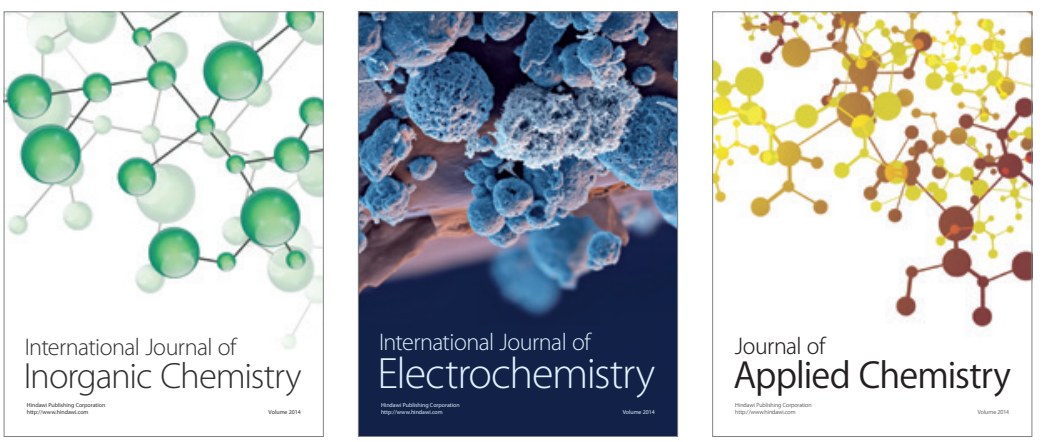

Journal of

Applied Chemistry
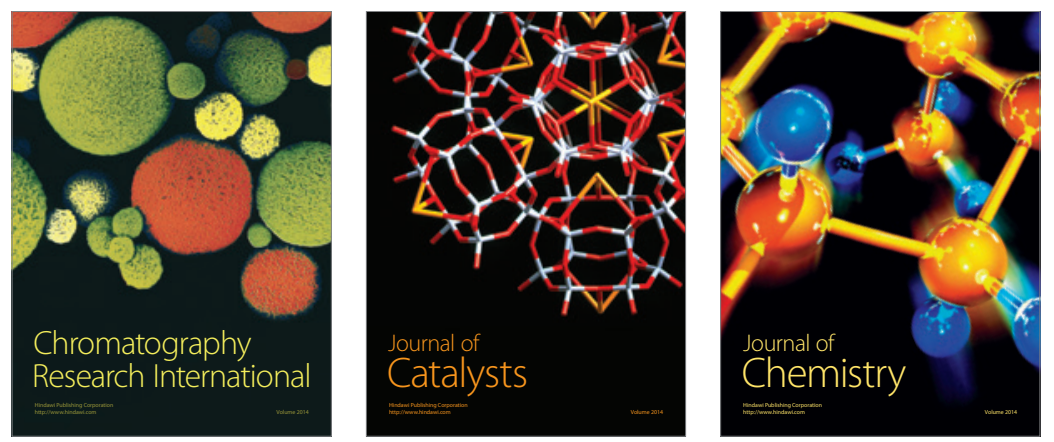
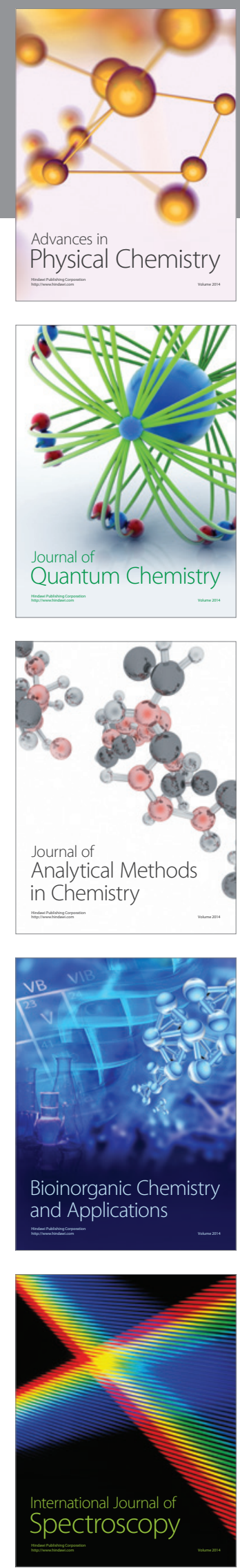